\title{
Isolation, Characterization and Bioactivities of Soil actinomycetes From the World Heritage Site (WHS) of Saint Katherine
}

\author{
Caroline M. Labib, Sahar A. El-Shatoury and A.Dewedar \\ Botany Department, Faculty of Science, Suez Canal University, \\ Ismailia, Egypt
}

\begin{abstract}
Q OIL ACTINOMYCETES were isolated from 10 different sites $\$$ in the World Heritage Site (WHS) of St. Katherine: Wadi El Deer, City center, Wadi El Talaa, Wadi El sheikh, Wadi El Arbean, Wadi El sheikh Awad, Wadi El Rutg, Om Kaisoum, Wadi Gebal, Gabal El Monagah. Simplified methods for isolation and characterization of actinomycetes recovered are described. Successful recovery was achieved on the media (S.C, 1/10 S.C and MGA). A total of 359 isolates were obtained and identified according to the standard macroscopic, microscopic as well as chemotaxonomy methods. A high percentage was obtained for Streptomyces, Nocardoides, Kitasatosporia spp. and unidentified spp., representing $30.4,23.7,11.4$ and $29.3 \%$, respectively. The metabolic extracts from 250 randomly selected isolates exhibited various antimicrobial activities towards one reference culture (E. coli NCMB 11943) and two clinical cultures (Staphylococcus aureus, Candida albicans). Variable activities were obtained with different actinomycete isolates; the highest activity was against the Gram +ve Staphylococcus aureus, followed by Candida albicans and the Gram -ve Escherichia coli. Organic extracts from 243 isolates were effective in causing more than $40 \%$ Ehrlich ascites carcinoma (EAC) cell death after 120 min. Micromonspora, Pseudonocardia and Streptomyces spp. metabolic extracts caused the highest percentage of EAC cell death that averaged $70.58,63.3$ and $61.5 \%$, respectively. Actinomycetes isolated from WHS Heritage Site of Saint Katherine are suggested to be a potential source of bioactive metabolites. In conclusion, desert actinomycetes represent a promising source for antimicrobial and antitumor bioactive agents. More attention should be paid to desert soils as unique habitat for actinomycetes, though further scientific evidence needs to be produced to verify the importance of these actinomycetes and their metabolites.
\end{abstract}

Keywords:Soil,Actinomycetes, Antitumor, Characterization, Isolation

Actinomycetes is considered as highly attractive cell factories, or bioreactors, for most applications in different fields. They are exceptionally rich, diverse and easily accessible sources for production of bioactive secondary metabolites. These secondary metabolites are usually species specific and embrace a very wide range of structural types with various biological activities. Many of these secondary metabolites are of fundamental industrial applications, such as vitamins, immunomodifiers, pigments, enzymes, enzymes - inhibitors, etc., and others have vital role in agricultural and environmental applications (Maheshwari et al., 2012). Members of the class Actinobacteria, and especially 
Streptomyces spp. have long been recognized as prolific sources of useful bioactive metabolites, providing more than half of the naturally occurring antibiotics discovered to date and continuing to be a source of new bioactive metabolites (Berdy, 2005). On the other hand Sterptomyces spp. has been related to some respiratory diseases which are caused often, by inhalation of its spores which present in bioaerosols (Kagen et al., 1981 and Van den Bogart et al., 1993). Toxins production by this genus can also result in health damage (Paananen et al., 2000). Some actinomycetes are pathogenic, such as Mycobacteriales. However, many others are extremely useful due to their ability to produce compounds with pharmaceutical properties (antibiotic, antifungal, antitumor, immunosuppressive). Actinomycetes are distributed extensively in soil and provide many important bioactive compounds of high commercial value, including many of medical importance (Takizawa et al. 1993 and Baltz, 2007). They also had a prominent position and have proved a major profilic source of most antibiotics, such as streptomycin, macracidmycin, kedarcidin and others. Of all the antibiotics discovered till now, $75 \%$ are produced by actinomycetes. (Chaudhary, 2013).

For many years, arid desert soils were considered economically unimportant, and any ecological research, including the examination of microbial characteristics, was sporadic. During the past two decades, however, the economic and agricultural utilization of arid lands has emerged as a critical element in maintaining and improving the world's food supply; consequently, biological and environmental research on these soils has increased. Desert soils are usually characterised by high soil $\mathrm{pH}$ and often by high salinity. Both of which influence the activities of soil microorganisms. Arid areas may include saline surface deposits and hypersaline bodies of water, inhabited by unique microbial population (Brock, 1979; Williams 1981). At the turn of the 20th century, most desert soils were considered abiotic and sterile. In 1912, Lipman first demonstrated that desert soils were inhabited by numerous microorganisms when he described microbiological and characteristics of California desert.

The WHS is characterized by a unique topography of high mountain range, associated with marked plant and animal biodiversity merging from the varying climatic conditions. Köppen-Geiger climate classification system classifies its climate as hot desert, with very low humidity (Egypt Climate Index, 2013). However, the site is still unexploited for microbial diversity and could be a valuable resource for novel actinomycetes of biotechnological value.

The aim of this work was to investigate the ability of actinomycetes isolated from desert habitat of the World Heritage Site (WHS) of Saint Katherine to produce bioactive compounds that may have antimicrobial and antitumor activities, under laboratory conditions.

Egypt. J. Bot., Vol. 56, No. r (2016) 


\section{Materials and Methods}

Site description and Soils Sampli

Soil Samples were collected in plastic bags during the early summer of 2005. Fifty soil samples were collected from 10 geographical sites. Each sample was collected in triplicates $(10-15 \mathrm{~cm})$ depth and a composite sample was used for actinomycetes isolation. with characteristic topography of high mountain range, associated with marked biodiversity merging from the varying climatic condition of WHS. The WHS Protectorate is an area of $601 \mathrm{~km} 2$ located within the 4350 $\mathrm{km} 2$ of Saint Katherine protectorate which is centered on the monastery of Saint Katherine.

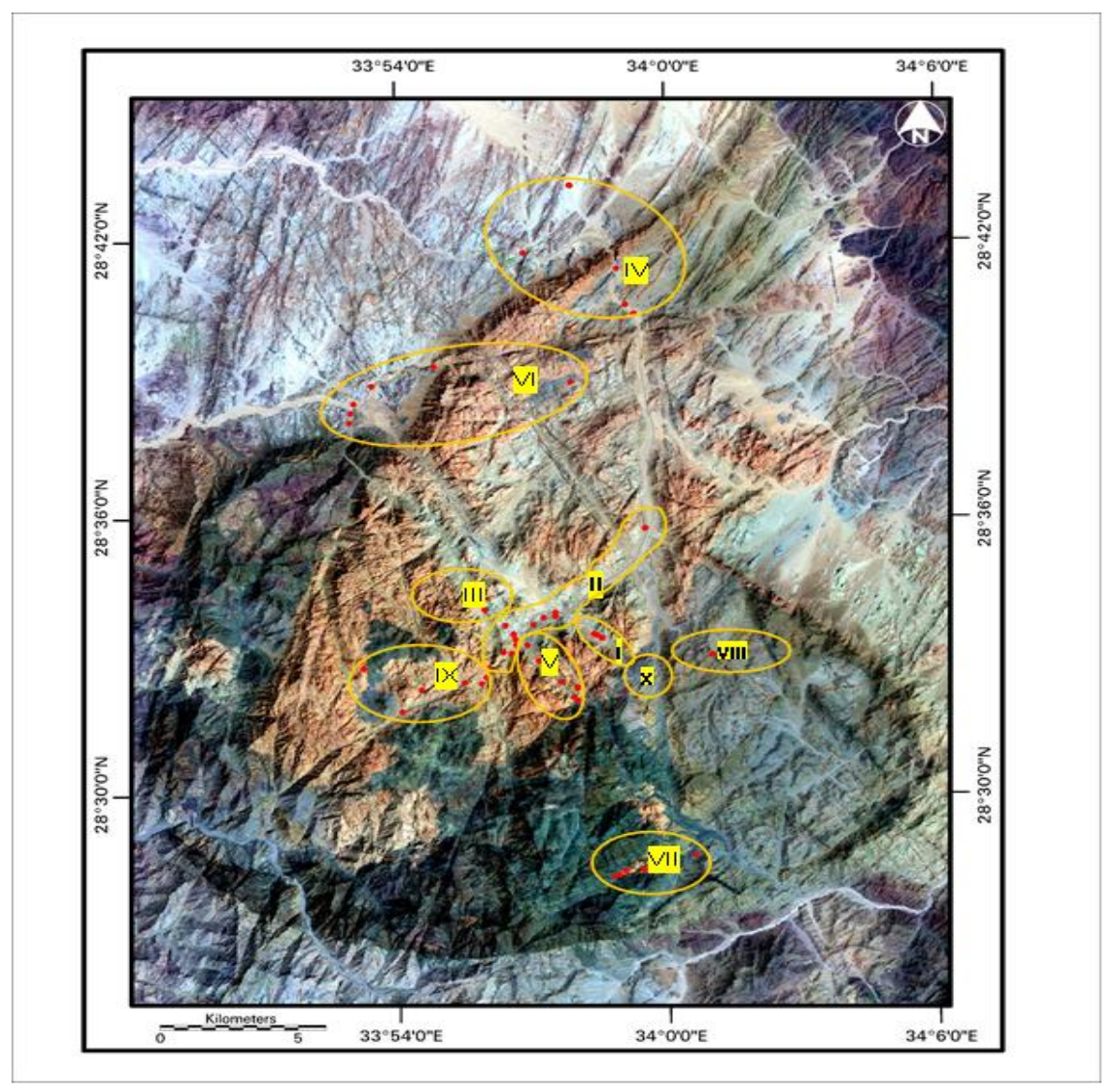

Soil analysis

Soil analysis was carried out in the Agriculture Research centers, Faculty of Agriculture, Suez Canal University. The investigated physico-chemical properties in this study were porosity, electric conductivity, $\mathrm{pH}$, chloride, total nitrogen, nitrate, and organic matter. 
Isolation and characterization of soil actinomycetes:

All procedures were performed in a laminar flow hood using standard aseptic techniques. Soil samples were processed with modification of the methods described by Demain and Davies (1999). Cyclohexamide antibiotic (50 mg/L) was used in all media to suppress fungi, permitting rare species to grow.

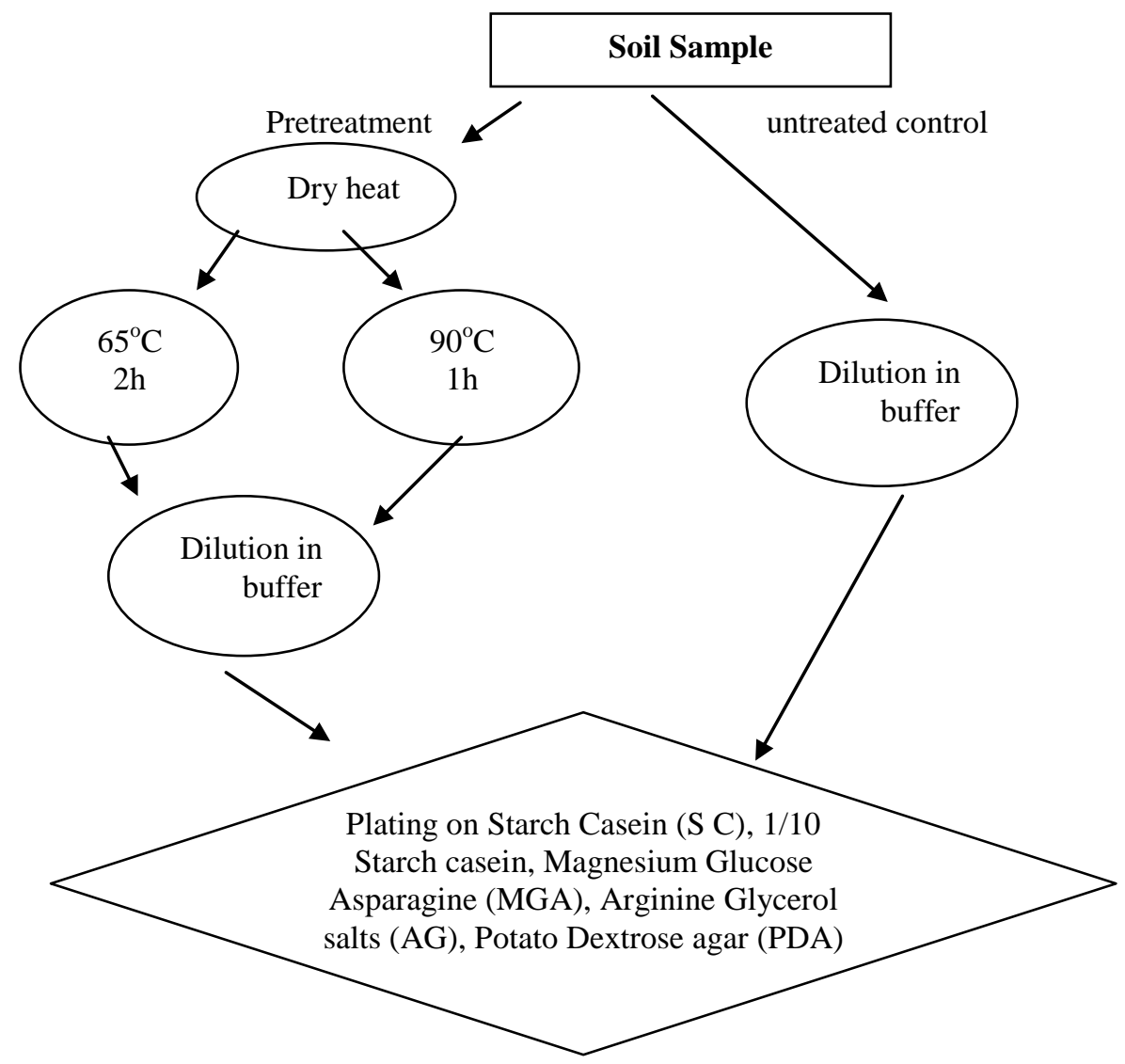

Proposed strategies for selection of optimal conditions for isolation of soil actinomycetes from the WHS soils.

Enumeration of soil actinomycetes

Soil samples (10-15 cm depth) were collected aseptically from the targeted localities and kept in sterile polyethylene bags at $4^{\circ} \mathrm{C}$ until analysis. Actinomycetes were isolated after serial dilution in phosphate buffer on SC agar supplemented with cycloheximide $(50 \mu \mathrm{g} / \mathrm{mL})$ using spread plate technique and applied for heat pretreatment technique for selecting the best isolation technique. Counts were recorded after incubation for 2-3 weeks at $28^{\circ} \mathrm{C}$. 
Representatives of each colony form were picked-off from the isolation plates and streaked on SC medium to obtain pure cultures. They were then preserved as spore suspensions by in $20 \%$ glycerol at $20^{\circ} \mathrm{C}$ (Kieser et al., 2000). Isolates were characterized and identified up to the genus level based on the standard methods (Holt et al., 1994). These were macromorphology, micromorphology, and chemotaxonomy (detection of diaminopimelic acid (DAP) isomers in the whole cell hydrolysate and whole cell diagnostic sugar pattern)

\section{Fermentation procedure}

Preserved spore suspensions of actinomycete isolates were inoculated into 30 $\mathrm{mL}$ of SC broth and incubated in a shaker incubator for 5-7 days at $28^{\circ} \mathrm{C}, 100$ rpm (Kieser et al., 2000). Cultures were extracted using equal concentrations of ethyl acetate, for three successive times with vigorous shaking for $30 \mathrm{~min}$. The ethyl acetate fractions were evaporated under vacuum into a preweighed vial and then redissolved in ethyl acetate giving a final concentration of $10 \mathrm{mg} / \mathrm{mL}$.

\section{Antimicrobial Screening:}

Metabolic organic extracts from the 900 isolates were tested by disc diffusion method at $0.1 \mathrm{mg} /$ disc against human pathogenic microorganisms (Castillo et al. 2002). The tested microorganisms were one reference bacterial strain Echerichia coli NCMB 11943 and two clinical cultures Staphylococcus aureus and Candida albicans (obtained from Suez Canal University, Dermatology clinic lab.). The growth medium used for bacterial culturing was nutrient broth and for the fungal culture was Sabouraud dextrose liquid medium.

\section{Antitumor Screening}

Induction of EAC in mice

Female mice (Swiss albino) of 20-25 gm body weight were injected with a fixed number of viable cells of Ehrlich ascites carcinoma EAC supplied from National Cancer Institute, Cairo University; $\left(5 \times 10^{6}\right.$ cells/20 gm body weight in $500 \mu \mathrm{l}$ sterile saline); into the abdominal cavity of each mouse by intraperitoneal (i.p.) injection using sterile syringe. These mice were kept in well- ventilated cages under standard conditions at room temperature, pressure, and humidity. The animals were provided with common diet and water ad libitum for about 10-15 days. After this period the tumor cells multiplied relatively freely within the peritoneal cavity. Tumor growth in each animal was monitored by recording daily weight change of mice and measuring of abdominal volume. EAC cells were withdrawn by sterile disposable syringe to detect the volume of tumor cells/mouse and then diluted with physiological buffer for further investigations. The viability of the cells was $99 \%$ as judged by trypan blue assay.

\section{In vitro trypan blue assay}

Different concentrations of each actinomycetes metabolic extracts out of 240 extracts (50 to $500 \mu \mathrm{g} / \mathrm{ml}$ ) were prepared in clean vials. Then each extract was treated with EAC cells $\left(12.2 \times 10^{6}\right.$ cells $/ \mathrm{ml}$ phosphate buffer $)$. The treated 
extracts were incubated for $2 \mathrm{hr}$ at $37^{\circ} \mathrm{c}$. Trypan blue cell count was conducted to evaluate the total number of viable and apoptotic cells according to the method of Mclimans et al. (1957). Trypan blue works by leaking into cells with damaged cell wall and dyeing their nucleus with blue color. After the incubation period, $2 \mu \mathrm{l}$ of $50 \%$ trypan blue was added to $18 \mu \mathrm{l}$ of the EAC mixture and microscopically counted using hemocytometer. Cells that showed signs of staining with blue were recorded as dead.

\section{Results}

Soil characteristics for the ten locations are presented in Table 1. The EC showed variation in the different locations of the study area with a maximum of $0.92 \mathrm{dSm}^{-1}$ in Wadi El Rutg and minimum of $0.15 \mathrm{dSm}^{-1}$ in Wadi El Sheikh. The soil of the study area, generally, had neutral to alkaline $\mathrm{pH}$, with a maximum of 8.17 in Wadi El Sheikh and a minimum of 7.48 in Wadi El Rutg. The value of chloride concentration in Wadi El Arbaen was notably higher $(85.2 \mathrm{mg} / \mathrm{kg})$ than other soil samples (ranged from $14.00-53.25 \mathrm{mg} / \mathrm{kg}$ ). Notably, the values of total nitrogen, nitrates, and organic matter in soil samples of Wadi El Sheikh Awad and Wadi El-Tofaha were low, compared to the other soils; being in the average of $50 \mathrm{mg} / \mathrm{kg}, 13.5 \mathrm{mg} / \mathrm{kg}$, and $0.101 \%$, respectively. While, the values of total nitrogen, nitrates, and organic matter ranged from 80 to $350 \mathrm{mg} / \mathrm{kg}, 18$ to $22 \mathrm{mg} / \mathrm{kg}$, and 0.163 to $0.691 \%$, respectively, in the soils from the other locations.

TABLE 1. Chemical characters of soil samples representing the different investigated locations within the St. Katherine WHS

\begin{tabular}{|c|c|c|c|c|c|c|c|c|c|c|}
\hline 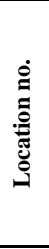 & Location name & $\begin{array}{l}\widehat{\Xi} \\
\stackrel{5}{*}\end{array}$ & 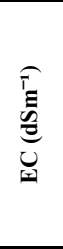 & 를 & 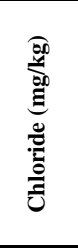 & 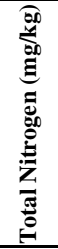 & 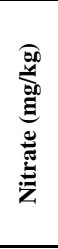 & 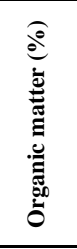 & 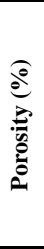 & 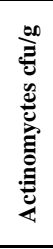 \\
\hline $\bar{I}$ & Wadi El deer & $1567-600$ & 0.31 & 7.79 & 17.75 & 120 & 18.0 & 0.244 & 18 & 48 \\
\hline II & City center & $1545-628$ & 0.32 & 7.75 & 14.00 & 50 & 14.0 & 0.102 & 18 & 26.1 \\
\hline III & Wadi El Talaa & 1627 & 0.35 & 7.93 & 53.25 & 115 & 18.0 & 0.229 & 20 & 7 \\
\hline IV & Wadi El Sheikh & $1177-307$ & 0.15 & 8.17 & 21.3 & 80 & 17.0 & 0.163 & 25 & 47 \\
\hline $\mathrm{V}$ & Wadi El Arbaen & $1635-750$ & 0.56 & 7.68 & 85.2 & 150 & 19.0 & 0.295 & 15 & 39.2 \\
\hline VI & Wadi El Sheikh awad & $1102-95$ & 0.20 & 7.78 & 28.4 & 50 & 13.0 & 0.100 & 16 & 76.8 \\
\hline $\begin{array}{l}\text { VI } \\
\text { I }\end{array}$ & Wadi El Rutg & $1585-647$ & 0.92 & 7.48 & 21.3 & 350 & 18.0 & 0.691 & 11 & 9 \\
\hline $\begin{array}{l}\text { VI } \\
\text { II } \\
\end{array}$ & Om Kaithoum & 1641 & 0.28 & 7.97 & 21.3 & 200 & 19.0 & 0.406 & 13 & 11 \\
\hline IX & Wadi Gebal & $1641-892$ & 0.31 & 7.81 & 19.53 & 155 & 20.0 & 0.270 & 13 & 42 \\
\hline $\mathrm{X}$ & Gabal El Monagah & 1600 & 0.30 & 7.82 & 21.3 & 190 & 22.0 & 0.386 & 2 & 57 \\
\hline
\end{tabular}

Egypt. J. Bot., Vol. 56, No. r (2016) 
Isolation and phenotypic characterization of actinomycetes from WHS soil:

An initial optimization step was done on 2 random samples to investigate the suitable dilution and treatment technique for the isolation. Direct isolation from diluted soil samples on agar media has resulted in overgrowth of fast growing bacteria and fungi, while dilution technique after soil pretreatment using two different conditions of dry heating showed successful results (Fig $1 \mathrm{a}, \mathrm{b}$ ). The 65 ${ }^{\circ} \mathrm{C}$ for two hours gave selective growth and complete apparent colony growth (i.e mature colonies) of actinomycetes on the isolation plates, while the $90{ }^{\circ} \mathrm{C}$ for two hours showed successful growth but with lack of aerial mycelia. The best actinomycetes growth from soil sample of location no. II was obtained on SC medium, while from soil sample of location no. IV the best growth was on SC and MGA media.

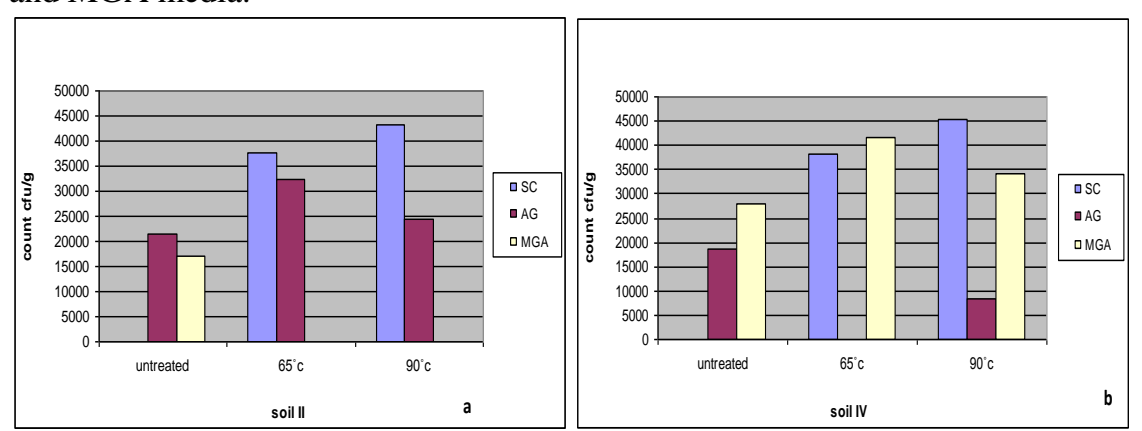

Fig. 1. Dry heating for selecting the best treatment technique before isolation, (a) soil sample of location II and (b) soil sample of location IV.

The second step of optimization was to select the best media for isolation. Ten random samples representative for the ten locations of WHS, were heat treated $\left(65^{\circ} \mathrm{C} / 2 \mathrm{~h}\right)$ and used for isolation on 5 different media: starch casein (SC), 1/10 starch casein, modified Magnesium Glucose Asparagin (MGA), potato dextrose agar medium (PDA) and Arginine Glycerol salts medium (AG). As shown in Fig. 2, MGA, SC and 1/10 SC gave varying counts of actinomycetes. While, AG and PDA media showed non remarkable counts and limited colony variations of actinomycetes on plates, therefore, their results were not represented in Fig 2.

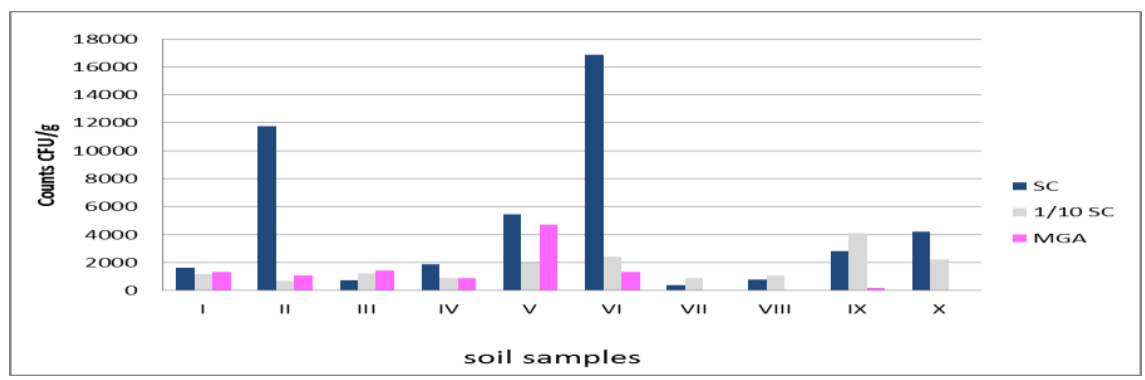

Fig. 2. Counts of actinomycetes on different media using random samples from the ten localities of WHS.

Egypt. J. Bot., Vol. 56, No. r (2016) 
In this study 359 actinomycete isolates were recovered from WHS soil. Marked differences in the micromorphology of these isolates under study adding to their chemotaxonomic criteria resulted in assigning of $70.75 \%$ of the isolates into 12 genera (Fig. 3 a). While the remaining 105 isolates $(29.25 \%)$ could not be identified, using the standard chemotaxonomic and morphological criteria (Fig 3 b). The major cluster groups were Streptomyces, Nocardioides and Kitasatosporia genera. Streptomyces strains were the cluster group with the largest number of isolates $(30.4 \%)$. Nocardioides strains also represented about $23.67 \%$. Kitasatosporia strains were recovered with the percentage of $11.4 \%$. In addition, rare genera such as Spirellospora, Nocardiopisis, Saccharopolyspora, Amycolata, Micromonospora, Pseudonocardia, Actinomadura, Promicromonospora and Actinoplanes were recorded.
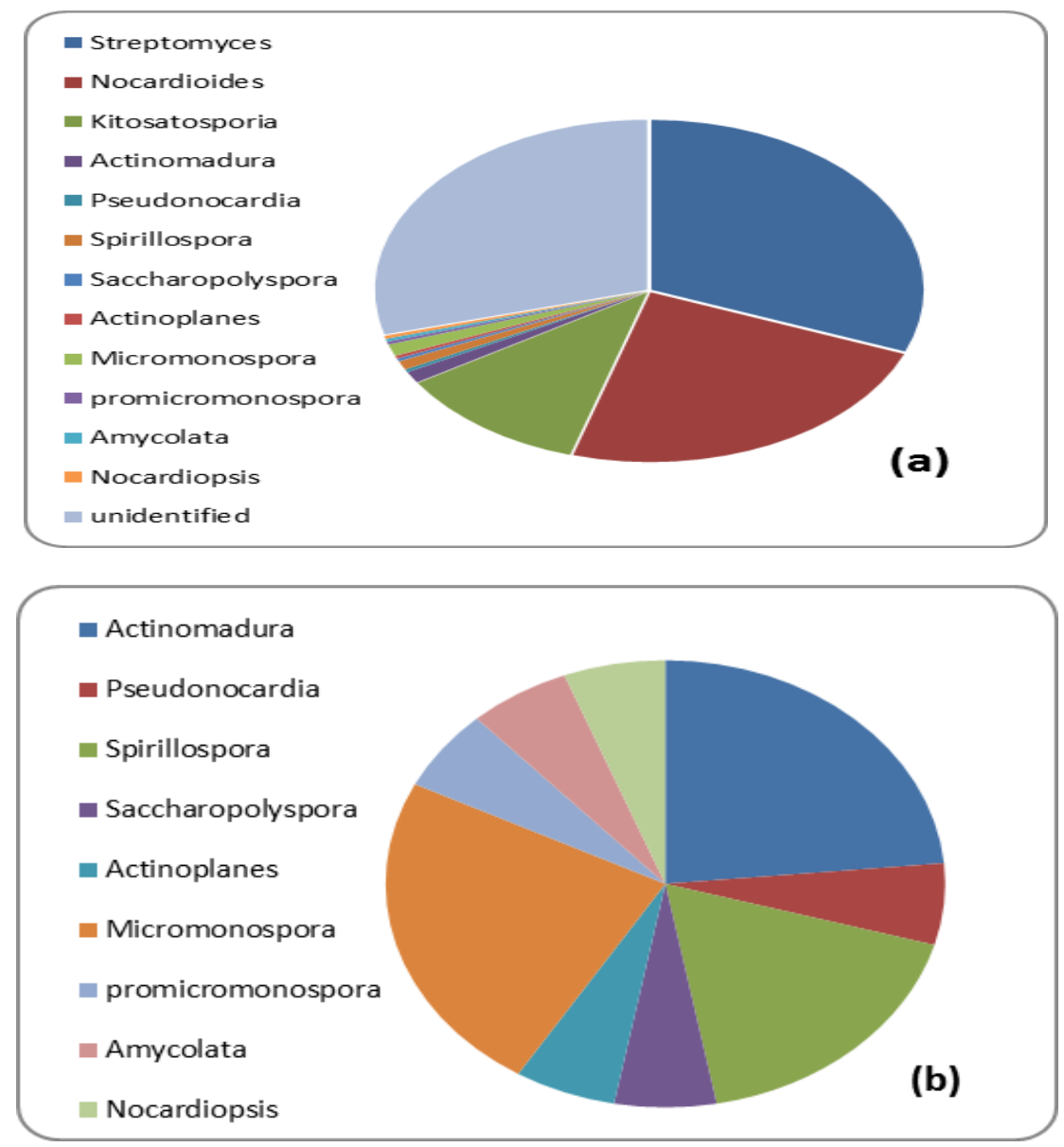

Fig. 3. Presumptively identified actinomycete genera in St. Katherine WHS soils.

(a) propotion of the 12 genera. (b) propotion of minior groups.

Egypt. J. Bot., Vol. 56, No. r (2016) 
Antimicrobial activities of actinomycete metabolic extracts

The metabolic extracts from representative 250 isolates were screened for antimicrobial activity. They exhibited various activities towards the reference culture (E. coli NCMB 11943) and two clinical cultures (Staphylococcus aureus and Candida albicans) obtained from Suez Canal University, Dermatology clinic lab. The 6 isolates belonging to the genera Spirellospora (3 isolates), Saccharopolyspora (1 isolate), Promicromonospora (1 isolate), and Actinoplanes (1 isolate), didn't show antimicrobial activities as illustrated in Table 2. Generally, the highest activity was against the Gram +ve Staphylococcus aureus followed by Candida albicans and the Gram -ve Escherichia coli.

TABLE 2. Antimicrobial activity of selected actinomycetes against E. coli, S. aureus and C. albicans.

\begin{tabular}{|l|c|c|c|c|}
\hline \multirow{2}{*}{ Genera } & \multirow{2}{*}{$\begin{array}{c}\text { No.of } \\
\text { isolates }\end{array}$} & \multicolumn{3}{|c|}{ No. of positive isolates } \\
\cline { 3 - 5 } & & E. coli & S. aureus & C. albicans \\
\hline Streptomyces & 77 & 30 & 38 & 27 \\
\hline Nocardioides & 41 & 12 & 23 & 22 \\
\hline Kitasatosporia & 28 & 7 & 8 & 11 \\
\hline Actinomadura & 3 & 2 & 2 & 2 \\
\hline Pseudonocardia & 2 & 2 & 2 & 2 \\
\hline Micromonospora & 1 & 1 & 1 & 1 \\
\hline Unknown & 94 & 43 & 55 & 48 \\
\hline \multirow{2}{*}{ Total } & 250 & 97 & 129 & 113 \\
\hline
\end{tabular}

Antitumor activities of actinomycete metabolic extracts:

Organic extracts from 243 isolates of the 250 actinomycetes were effective in causing more than 40\% EAC cell death after 120 min (Table 3). Micromonospora, Pseudonocardia and Streptomyces spp. metabolic extracts caused the highly percentage of EAC cell death that was calculated as 70.58 , 63.3 and $61.5 \%$, respectively. There were only 4 genera showed no effect with EAC cells identified as Promicromonospora, Actinoplanes, Spirillospora, ,

Saccharopolyspora spp.

Dead EAC cells percentage $=($ total number of EAC cells - number of living EAC) / total number of EAC cells * 100. The Trypan blue stain was used as indicator for counting the dead cells. The living cells were transparent and the dead ones were blue.

\section{Discussion}

In Egypt, the desert habitats represent about $94 \%$ of the land and are less studied (Hozzein, 2000; Hozzein et al., 2007). Because of being one of the Egyptian desert habitats, it is interested to screen the WHS actinomycetes as a new source for production of novel active compounds. The present study 
highlights the ability of these actinomycetes isolated to produce bioactive compounds that have antimicrobial and antitumor effects. Soil samples were collected from ten locations in the WHS and investigated for the diversity of actinomycetes. Soil characters and analysis for the ten areas indicated a poor organic nature of the study area.

TABLE 3. Ehrlich Ascites Carcinoma (EAC) inhibition by metabolic extracts from different actinomycetes genera.

\begin{tabular}{|l|c|}
\hline \multicolumn{1}{|c|}{ Actinomycetes isolates } & \% of dead EAC cells \\
& \\
\hline Streptomyces $(76)$ & 61.49 \\
\hline Nocardoides $(41)$ & 56.7 \\
\hline Micromonospora (1) & 70.58 \\
\hline Kitasatosporia $(28)$ & 57.2 \\
\hline Pseudonocardia $(2)$ & 63.33 \\
\hline Actinomadura $(1)$ & 57.13 \\
\hline Unknown spp. $(94)$ & 52.05 \\
\hline Promicromonospora $(1)$ & ---- \\
\hline Actinoplanes $(1)$ & ---- \\
\hline Spirellospora $(1)$ & ---- \\
\hline Saccharopolyspora $(1)$ & ---- \\
\hline
\end{tabular}

Actinomycete counts ranged between $7 \times 10^{3}-47 \times 10^{3} \mathrm{cfu} / \mathrm{g}$. Results were in agreement with those previously reported for other sites in Saint Katherine desert where counts ranged between $5 \times 10^{3}-59 \times 10^{3} \mathrm{cfu} / \mathrm{g}$ (Mansour, 2003), showed significant differences among the studies soil ecosystems. Rapidly growing bacteria and spreading of fungi often mask the presence of actinomycetes; this is one of the main reasons why actinomycetes isolation from the soil is difficult. Therefore, pretreatment of the sample or the applications of selective antibiotic are needed (Matsukuma et al., 1994). In this study, cycloheximide was effective to inhibit fungal growth; similar result was reported by Castillo et al. (2007). Also, using a range of different media can increase the number and range of recovered actinomycetes (Goodfellow and Williams, 1983; McCarthy and Williams, 1992). Different isolation media were used in this study and only three media (SC, 1/10 SC and MGA) showed efficient recovery of high counts and morphologically diverse actinomycetes colonies. Starch casein medium, in particular, showed efficient recovery of soil actinomycete. Also, the low nutrient content media 1/10 SC was effective in the current study and prevented fast growing fungi and unicellular bacteria. McCarthy and Williams (1992) have described an autochthonous behavior - i.e. sustained growth at low nutrient concentrations - amongst actinomycetes, which may explain the successful selectivity of the low nutrient medium for actinomycetes. 
Streptomyces isolates were found to represent $30.4 \%$ of the isolates, and was recovered from all locations except Wadi El-Rutg and Gabal Al- Monagah where there were relatively high values of organic matters, nitrates, total nitrogen and low porosity. It is worth noting that Wadi El Tofaha, Wadi El-Sheikh Awad and Wadi El Sheikh showed low values of nitrates, total nitrogen and organic matters, with high count of actinomycetes and high frequency. Also, Wadi El Tofaha showed highest percentage of diversity of Streptomyces, Nocardioides and unidentified isolates, which may be a valuable finding for further investigations.

Actinomycetes are one of the predominant members of soil microbial communities and they have beneficial roles in soil nutrients cycling and agricultural productivity (Elliot and Lynch, 1995). With the exception of pasture, soil factors such as $\mathrm{pH}$ and salinity do not significantly affect actinomycetes population in the different soil ecosystems studied. The effect of salinity on microbial biomass and activity is not uniform and the observed differences may be due to the composition of the pool of soluble ions as well as the presence or absence of plant and agricultural activities. In this study there is a difference in the number of actinomycetes that was observed comparing with electrical conductivity differences. This observation does not support the conclusion of Chowdhury et al. (2011) that the combined effects of matric and osmotic potential in saline soils is more important for microbial biomass than electrical conductivity.

Actinomycetes participate in many important biochemical processes in the soil. In addition, many species have the capacity to elaborate potent antimicrobial substances. Screening for antimicrobial activity indicated a prominent antibacterial effect, worthy of further investigation for isolates belonging to 6 genera of total 12 identified genera, which were Streptomyces, Nocardioides, Kitasatosporia, Micromonspora, Pseudonocardia, Actinomadura, adding to 94 unidentified isolates. The antimicrobial activity of Streptomyces was previously reported in Zin et. al, 2011 and Abussaud et. al, 2013. Also the antimicrobial activity of Nocardioides was studied and reported by El Refai, et. al, 2011. The genus Kitasatosporia also was studied for producing antifungal compound and reported by Young Ryun Chung et al. (1999) which may agree with this study result; where $50 \%$ of Kitasatosporia isolates showed positive activity. Antitumor screening of the isolates in this study revealed the ability of 243 isolates, of 250 isolates, to inhibit Ehrlich ascites carcinoma cells (EAC cells). Micromonospora, Pseudonocardia and Streptomyces spp. metabolic extracts caused high percentage of EAC cell death that averaged 70.58, 63.3 and $61.5 \%$ respectively.

In conclusion, WHS soil actinomycetes represent a promising source for antimicrobial and antitumor bioactive agents. More attention should be paid to desert soils as unique habitat for actinomycetes, to verify their important metabolites.

Egypt. J. Bot., Vol. 56, No. r (2016) 


\section{References}

Abussaud, M. J., Alanagreh, L. and Abu-Elteen, K. (2013) Isolation, characterization and antimicrobial activity of Streptomyces strains from hot spring areas in the northern part of Jordan. African Journal of Biotechnology, 12.51 (Dec 18, 2013): 7124-7132.

Baltz Richard H., (2007) Antimicrobials from Actinomycetes: Back to the Future. Actinomycetes are the source of most clinically relevant antibiotics in use today and may continue to be so. 2, 3, Microbe 125-131

Berdy (2005): Bioactive microbial metabolites. Bérdy J. Erratum in J Antibiot (Tokyo).

Brock, T. D. (1979): Ecology of saline lakes. M. ShiloStrategies of microbial life in extreme environments. Verlag Chemie. Weinheim, 29-47

Castillo U.F., Strobel G.A., Ford E.J., Hess W.M, Porter, H., Jensen, J.B., Albert, H., Robison, R., Condron, M.A., Teplow, D.B., Stevens, D., Yaver, D., (2002) Munumbicins, wide-spectrum antibiotics produced by Streptomyces NRRL 30562, endophytic on Kennedia nigriscans. Microbiology 148, 2675-2685

Castillo U.F., Browne L., Strobel G., Hess W. M., Ezra S. and Pacheco G. (2007): Biologically active endophytic Streptomycetes from Nothofagus spp. and other plants in Patagonia. Microb. Ecol.53, 12-19. 10.1007/s00248-006-9129-6.

Chowdhury, N., Marschner, P., Bums, R.G., (2011) Response of microbial activity and community structure to decreasing soil osmotic and matric potential. Plant Soil. In press

Chaudhary Hotam Singh, Bhavana Soni, Anju Rawat Shrivastava, Saurabh Shrivastava (2013): Diversity and Versatility of Actinomycetes and its Role in Antibiotic Production. Journal of Applied Pharmaceutical Science 3 (8 Suppl 1) S83S94.

Demain and Davies, (1999) Manual of Industrial Microbiology and Biotechnology Hardcover - 1 Apr 1999, by Arnold L. Demain, Julian Davies, Ronald M. Atlas, Gerald Cohen, Charles Hershberger, Wei-Shou Hu and David Sherman (Ed), Richard Willson, J. David Wu (Ed).

El-Refai, H.A., AbdEIRahman , H.Y., Abdulla, H. , Hanna, Atef G. , Hashem, A.H. , El-Refai A.H. and Ahmed, E.M. (2011) Studies on the Production of Actinomycin by Nocardioides luteus, a Novel Source. Current Trends in Biotechnology and Pharmacy. 5 (3) 1273 -1281 July 2011, ISSN 0973-8916 (Print), 2230-7303 (Online).

Elliot, L.F. and Lynch, J.M. (1995) The international workshop on establishment of microbial inocula in soils: cooperative research project on biological resource management of the Organization for Economic Cooperation and development (OECD). American Journal of Alternative Agriculture.10, 50-73.

Goodfellow, M. and Williams, S.T. (1983) Ecology of actinomycetes. Ann Rev Microbial 73, 189-216.

Egypt. J. Bot., Vol. 56, No. r (2016) 
Holt, J.G., Krieg, N.R., Sneath, P.H.A., Staley, J.T., Williams, S.T. and (1994) Bergey's Manual of Determinative "Bacteriology. Williams \& Wilkins, Baltimore", USA.

Hozzein W.N. (2000) Production of certain bioactive compounds bysome microorganisms from Wadi Araba, Egypt. M.Sc. thesis, Botany Dept., Faculty of Science, Cairo University, Cairo, Egypt.

Hozzein W.N., Ali, D.M.I. and Ali, M.I.A. (2007) Genus diversity and antibacterial activities of some desert actinomycetes. J. Union Arab. Biologists, 17B, 15-30.

Kagen, S.L., Fink, J.N., Schlueter, D. P., Kurup, V.P., and Fruchtman, R.B. (1981) Streptomyces albus: A new cause of hypersensitivity pneumonitis. Journal of Allergy and Clinical Immunology, 68, 295-299.

Kieser, T., Bibb, M.J., Buttner, M.J., Chater, K.F. and Hopwood, D, (2000) Practical Streptomyces genetics. The John Innes Foundation, Norwich.

Maheshwari, D.K., Dubey R. C. and Saravanamurthu, R. (2012) Industrial Exploitation of Microorganisms (edn), chapter 15: R. Balagurunathan and $\mathrm{M}$. Radhakrishnan.

Mansour, S.R. (2003) The occurrence and distribution of soil actinomycetes in Saint Catherine area, South Sinai, Egypt. Pak J Biological Sci. 6 (7), 721-728

Matsukuma, S., Okuda, T., and Watanabe, J. (1994): Isolation of actinomycetes from pine litter layers. Actinomycetologica, 8: 57-65.

McCarthy, A.J. and Williams, S.T. (1992) Actinomycetes as agents of biodegradation in the environment - a review. Gene., 115: 189-192.

McLimans, W.F., Davis, E.V., Glover, F.L. and Rake, G.W., (1957) The submerged culture of mammalian cells: the spinner culture. J. Immunol ,79: 428-433

Paananen Auli, Raimo Mikkola, Timo Sareneva, Sampsa Matikanen, Maria Andersson, Ilkka Julkunen, Mirja S. Salkinoja-Salonen and Tuomo Timonen (2000): "Inhibition of Human NK Cell Function by Valinomycin, a Toxin from Streptomyces griseus in Indoor Air',

Takizawa M., Colwell, R.R. and Hill, R.T. (1993) Isolation and diversity of actinomycetes in the Chesapeake Bay. Appl. Environ. Microbiol, 59: 997-1002.

Van den Bogart, H.G.G., van den Ende, G., van Loon P.C.C. and van Griensven LJLD. (1993): Mushroom workers lung; serologic reactions to thermophilic actinomycetes present in the air of compost tunnels. Mycopathologia; 122: 21-28

Williams, W.D. (1981) The limnology of saline lakes in Western Victoria - a Review of some recent studies Hydrobiologia, pp. 233-259.

Young Ryun Chung, Kee Cheol Sung, Hye Kyoung Mo, Dae Young Son, Jin Sik Narn Jongsik Chun and Kyung Sook Bae, (1999) Kitasatospora cheerisanensis sp. 
nov., a new species of the genus Kitasatospora that produces an antifungal agent. International Journal of Systematic Bacteriology ,49: 753-758

Zin, N.Z. Mohamad, Nor Asmara Tasrip, Mohd Nasir Mohd Desa, Cheah Yoke Kqueen, Zainul Amiruddin Zakaria, Rukman Awang Hamat and Mariana Nor Shamsudin, (2011) Characterization and antimicrobial activities of two Streptomyces isolates from soil in the periphery of Universiti Putra Malaysia. Tropical Biomedicine, 28 (3): 651-660

Received 26 /4 / 2016; accepted 28/11/2016)

\section{عزل وتعريف ودراسة النثاط الحيوى لاكتينوميستيك التربة في منطقة التراث العالمى بمحمية سانت كانرين}

كارولين لبيب ، سحر الثاتورى ـ أحمد دويدا

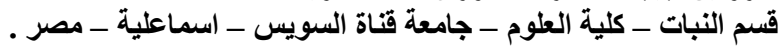

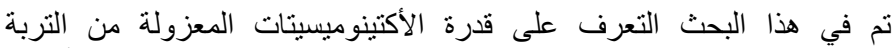

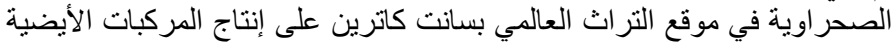

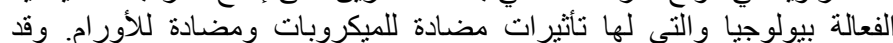

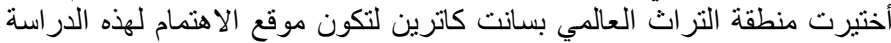

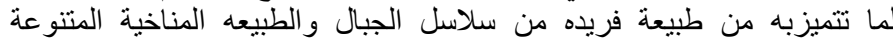

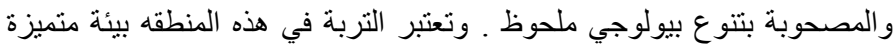

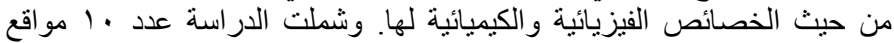

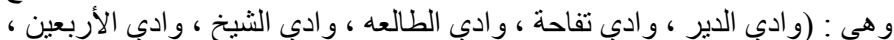

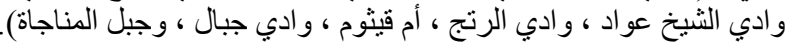

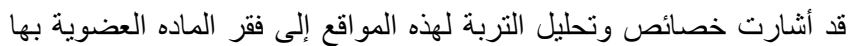

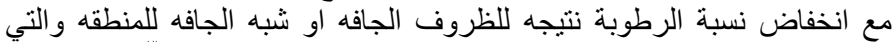

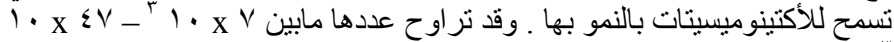

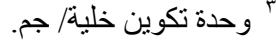

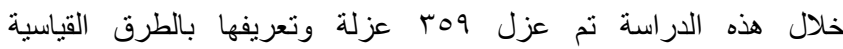

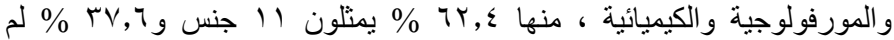

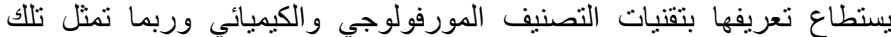

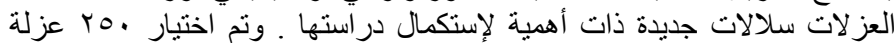

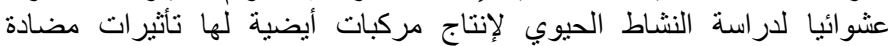

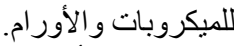

تم عزل أنواع من جنس ستربتوميسيس Streptomyces من جميع أماكن

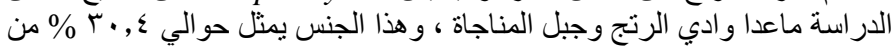

$$
\text { مجمل السلالات المعزولة مادئ. }
$$

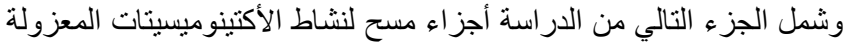

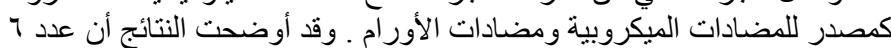

Egypt. J. Bot., Vol. 56, No. r (2016) 


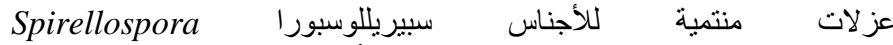

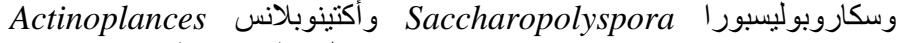
وبروميكرومونوسبور ا Promicromonospora لم تظهر نشاط ميكروبي ضدي

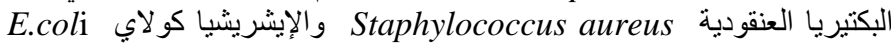

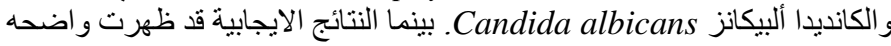
مع الانواع ستربتو ميسيس Streptomyces ونوكايدويدز

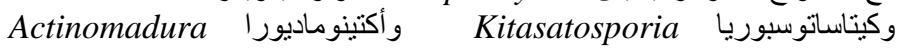
وسودونوكارديا Pseudonocardia وسياتونبا

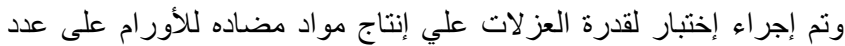

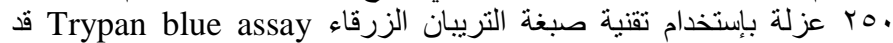

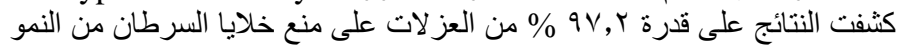

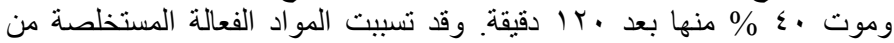

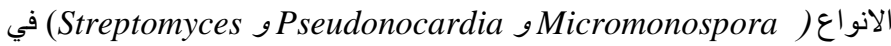

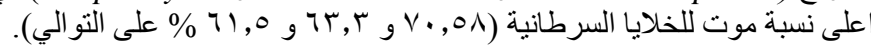

